Vol. 5 (2), pp. 033-042, April, 2015

ISSN: 2276-7797; ICV: 5.98

Copyright @2015, the copyright of this article is retained by the author(s)

DOI Link: http://doi.org/10.15580/GJMS.2015.2.082514335

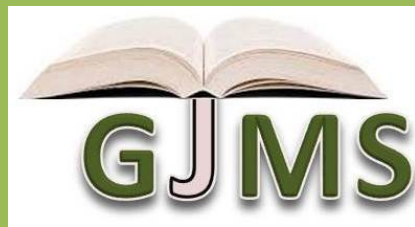

http://gjournals.org/GJMS

\title{
Evaluation of the Knowledge, Attitude and Practice of Kadutu population in Family Planning in South-Kivu, Democratic Republic of Congo
}

\section{KAVIRA Céline Malengera ${ }^{1,5,6 *}$, IMANI Prince Musimwa², MUSAMBA Philippe Teso ${ }^{3}$, MUHINDO Pamela Musimwa ${ }^{4}$}

\author{
${ }^{1}$ Research in Natural Sciences Center of Lwiro, Health Department, Protection Maternal and Infantile \\ Section, Maternity services; E-mail: kavira.celine@gmail.com \\ ${ }^{2}$ Panzi General Reference Hospital, Genecology Obstetric Department, \\ E-mail: princeimani12@gmail.com \\ ${ }^{3}$ Evangelic University of Africa, Environmental Department, South-Kivu, DRC; \\ E mail: kavimusumbateso@hayoo.fr \\ ${ }^{4}$ Central Prison of Bukavu, Health Department, Central Jail, South-Kivu, DRC. \\ E mail: drpamelamuhindo@gmail.com \\ ${ }^{5}$ Evangelic University of Africa, Faculty of Medicine and Community Health, South-Kivu, DRC. \\ 6Technics Medicals Institute /Kabare South-Kivu, DRC.
}

\section{ARTICLE INFO}

Article No.: 082514335

Type: Research

DOI: 10.15580/GJMS.2015.2.082514335

Submitted: $25 / 08 / 2014$

Accepted: $10 / 04 / 2015$

Published: $20 / 04 / 2015$

${ }^{*}$ Corresponding Author

Kavira Céline Malengera

E-mail: kavira.celine@gmail.com

Keywords:

Knowledge, Attitudes, Practice, Family Planning and Kadutu

\section{ABSTRACT}

The Maternal Health interest lies on both developed countries and under developed countries. Maternal mortality is a Public Health problem and Family Planning (FP) is one of strategies to reduce it. Even with the development of new strategies, pregnant women continue to die and the use of FP remains low. This study has been carried out in South-Kivu at Kadutu from May $09^{\text {th }}$ to June $19^{\text {th }}$ 2013 with the aim to evaluate the knowledge, attitude and practice of Family Planning (FP) among the population of Kadutu. A cross sectional study was conducted among 267 individuals using a well structured questionnaire. These individuals were selected through stratified random sampling. Data were analyzed using SPSS version 16.0 software. The results showed that the three major sources of information for the FP are radio, NPC and awareness campaigns respectively $34.5 \%, 21.7 \%$ and $9.4 \%$. Sixty four percent were not informed about FP the last two weeks before the study. The proportion of households under contraception is $26 \%$. Fifty four percent had heard information about FP. The respondents were not able to list the types of contraceptive use in this environment. The religious individuals have not heard about FP, the lack of availability of the inputs and the lengthy time used during counseling in the clinic of FP are the key factors responsible for the non-use of contraceptive methods in Kadutu Health Zone. The availability of input, the sensitization of the community, religious groups and men on the importance and the validity of FP is necessary. 


\section{ABBREVIATIONS}

ANC: Antenatal Care

DHS: Demographic Health Survey

FP: Family Planning

KAP: Knowledge, Attitude, Practice

NPRH: National Program of Reproductive Health

SPSS: Statistical Package for Social Sciences

UNICEF: United Nations Children's Fund

WHO: World Health Organization

\section{INTRODUCTION}

The Family Planning (FP) interests is on both the under developed countries and developed countries and it is one of components of Primary Health Care (WHO 1978, 1994 and 2000).

Among the objectives of the National Policy on Population in 2000, includes the improvement of the Reproductive Health of the population, the change of contraceptive practice and promotion of high use of Reproductive Health services particularly by women, young and adolescents to increase prevalence of modern contraceptive from 6\% in 1998 to $19 \%$ in 2015 (WHO, 2000).

According to Demographic Health Surveys, even though the policy has been implemented, the contraceptive prevalence is still low and the Maternal Mortality still higher (DHS, 2007, DRC). In this study, they showed the relationship between low contraceptive prevalence and rapid demographic growth. The latter contributes to the deterioration of the Community Health and of Maternal Infant-Juvenile Mortality (DHS, Ghana 2010, Benin 2009, DRC 2007 and of Rwanda 2010).

In Sub-Saharan Africa, poverty is an implicating factor influencing the use of contraceptive methods (Ross and Smith, 2011), while there are methods which are free but are still not used. Also, the religion barrier is also an influencing factor given by the Kadutu population.

Since two to three decades, fertility transition had already begun in the developed world and has already attained good success but in developing countries, it is still a problem.

Some authors think that for Africans to succeed in decreasing fertility, they must put much efforts in Family planning issues (Joseph and Garenne 2001) in order to contribute to reducing Maternal and Infant Mortality and bring about the development of nations (National Program of Reproductive Health, DRC, 2008). One of the factors in the recent decline in fertility observed in the countries that took part in EDS is contraceptive use (DHS, Benin 2009; WHO, Rapport of Millennium Objective 2009).

The DRC is one of countries which integrates the Family Planning in their Health Zone (NPRH in DRC, 2008), but adherence to contraceptive methods is still a problem and the cause of decrease in contraceptive prevalence to $7 \%$ in DRC (Mixed Inquiry by multiple indicators in DRC, 2010).

In South-Kivu, only 2 Health Zones $(\mathrm{HZ})$ out of 34 , were covered and the contraceptive prevalence and the fecundity rate are $14.8 \%$ and $13.5 \%$ respectively. The Kadutu Health Zone is not exempted, having a rate of 20.1\% (Rapport NPRH South-Kivu, 2012). In this area, religious, medical and economic barriers, the lack of information about FP, the non-availability of contraceptive methods in the Health Centers are factors indicated by the population as barriers of FP.

This KAP (Knowledge, Attitude and Practice) study wants to contribute to the promotion of Reproductive Health in South Kivu through an assessment of Knowledge, Attitudes and Practices of people in the Health Zone Kadutu on PF and identify barriers to contraceptive use.

\section{DESCRIPTION OF THE STUDING AREA}

The Health Zone of Kadutu belongs to Bukavu town principally in Kadutu community. Most of its population is found in Bagira community. Kadutu Zone surface area is $15 \mathrm{Km}^{2}$. It is limited at the North by the river Wesha which separates it from the Bagira Health Zone. it is separated in the South- East by Kawa river and along the industrial avenue which separates it from Ibanda Health Zone. At the West a Kawa river separates it from the rural Health Zone of Kabare and at the South-East Kadutu is bounded by Nyantende Health Zone. It consists of a mountainous terrain, a wet mountain climate, average temp of $15^{\circ} \mathrm{C}$ during the rainy season and $25^{\circ} \mathrm{C}$ in dry season. Located between $1500 \mathrm{~m}$ and $2190 \mathrm{~m}$ above sea level, its vegetation is savanna woodland.

This Health Zone contains about 46887 inhabitants. The Populations' occupations are principally minor trades, civil servants of the government and subsistence agriculture. The destruction of infrastructures and the economic components, social disruption of the public services of government have increased unemployment rate. The pauperization of the population has reduced the access to social services. There we find a cultural and ethnical mix-up leading to 
some cultures being forgotten. Actually, this Zone has the following sanitary formation: Four hospitals comprising: a Reference General Hospital of Ciriri with the capacity of 300 beds and 130 beds mounted, the general hospital of Kadutu with 100 beds mounted, the University Hospital of Bukavu (Muhanzi) with 60 beds and St Vincent Medical Center with 22 beds. There are also two specialized Centers: Psychiatric Center "SOZAME" and Physical Handicapped Center "HERI KWETU", At least, 11 Health Centers 14 over required, that is to say a sanitary covering is $78.57 \%$ (Annual Report of Kadutu Health Zone, 2012).

\section{MATERIALS AND METHOD}

This quantitative descriptive cross-sectional study was conducted from May 9 to June 19, 2013 in households of people of reproductive age. The health zones in the province of South Kivu have been involved in the study with a population of 46887 (NACP Report 2012). The following are the independent variables used to determine information on FP: Marital status, education level, occupation, date of birth, source of information, knowledge about contraceptive methods, knowledge on the significance of FP, knowledge of the benefits of FP, number of children, Use of contraceptive methods, availability of inputs, accessibility to get to the clinic, time is to be received at the clinic, FP information heard less than last two weeks. We selected use of contraceptive methods as the dependable variable. Ten interviewers were trained to gather data. They were informed about the ethical conditions and the sequence of data collection. . A closed questionnaire was given to the respondents to give their answers. After gathering data, we proceeded to verifying them, collection and analysis with an appropriate software. We have applied simple random sampling technique. Our sample was taken among the 45170 persons (Report of PNSR in SouthKivu, 2012) with 9486 women in reproductive age. Schwartz formula $D$. was use to calculate the simple size: $n \geq Z^{2}(1-\alpha / 2)(p)(1-p) / d^{2}$ (Therry et al., 2002). $Z^{2}{ }_{(1-}$ $\alpha / 2)$ : is the value of normal variable centred reduced which corresponds to the value of probability for confidence level to $95 \%$ ( it equals to 1.96 ), the wished precision is $5 \%, \mathrm{p}$ is the contraceptive prevalence at
Kadutu which is $20 \%$, q equals to (1-p) is the absence of the studied phenomenon's in the population. The formula has given us a sample of 243 . To maximize the participant rate of response to the inquiry, we have added $10 \%$, to this sample, which has given us a sample of 267 . To calculate the proportion of women under contraception and those who know about Family Planning, we calculated the frequency using the SPSS software. To indicate the relationship between dependent and Independent variables, we have used chi-square statistic test, the error Alpha is 5\% (the difference is considered significant if $p$ is inferior to 0.05 and the confidence level is $95 \%$ ). This study has included all the women in childbearing age except those who refused to sign the consent form, the ill persons unable to speak, non-inhabitants of the zone, deaf persons, dumb and the entire household that had individuals less than 15years or more than 49 years. A consent form was signed by the participants before their participation in the study.

\section{RESULTS AND DISCUSSION}

\section{Determination of Sources and Means of Information on Family Planning in the Study Area}

Figure 1 shows that in Kadutu, more than a quarter (92/267) or $34.5 \%$ received information about family planning on the radio, followed by those who have received the ANC (58/267) is $21.7 \%$, these two are the biggest sources of FP information in this country. Other sources of information forms the remaining proportions and most are insignificant. It is too bad that radio informs a sufficient number of people even when journalists do not undergo training in this area, and may distort the message leading to all possible consequences. These results are similar to those found in Benin in 2002, which found that the two main sources of information are the radio and social agents (Borgou and Alibori, 2002). In principle, reproductive health providers involved in community shifts should be the main sources of information on FP, since they the ones who are trained and know how to convey the message to the target population. 


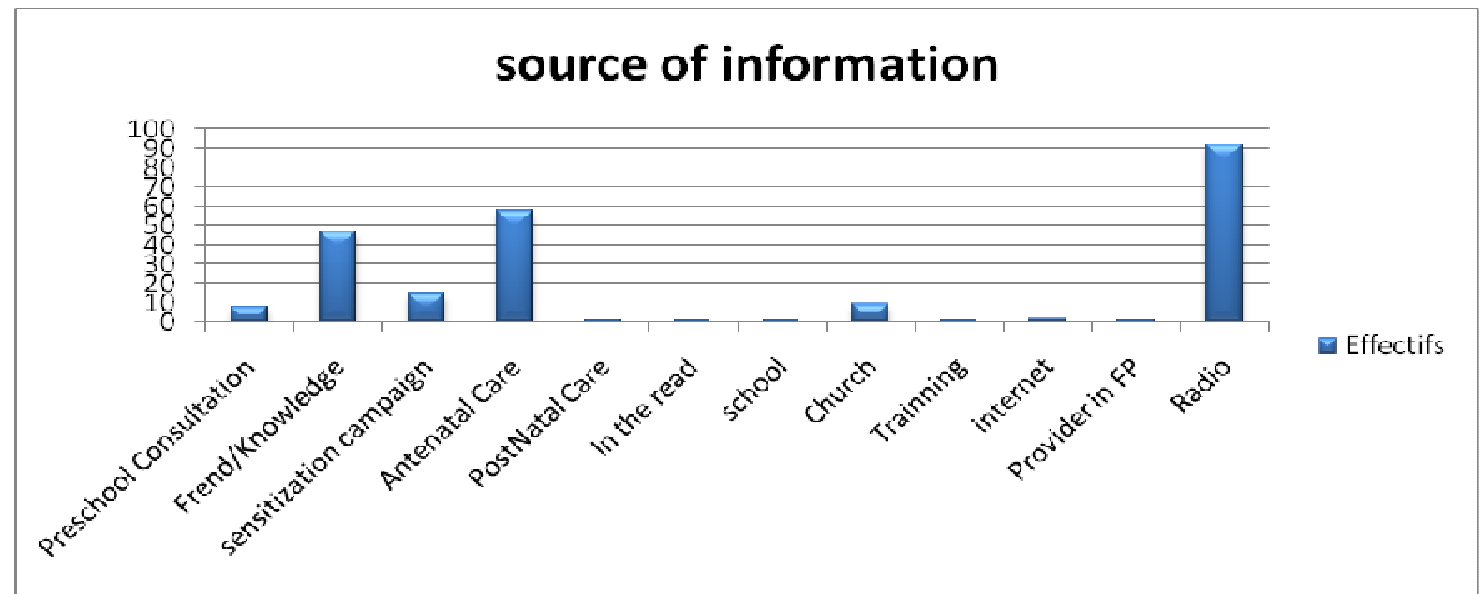

Figure 1 : Sources of information on the Family Planning at Kadutu

\section{Proportion of Households under Contraception}

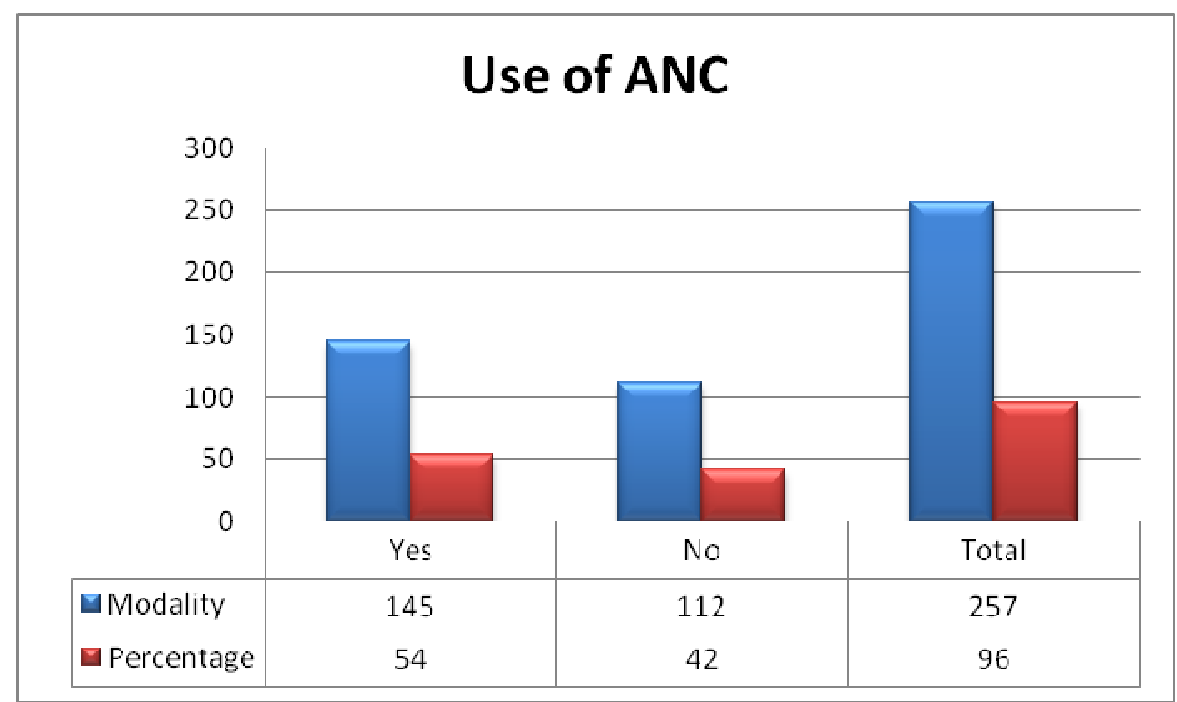

Figure 2: Proportion of household using contraceptive in Kadutu Health Zone

Figure 2 shows that of 267 households surveyed, 145 or $54 \%$ did not use contraception and (112/267) or $42 \%$ used, ten households did not respond on this issue. With Kadutu being an urban environment, this proportion is low. Mamadou Cherif in Guinea (Mamadou, 2008) found the opposite results while his study population was urban. It is essential to continue with awareness on FP because the level of use of contraception is one of b) the indicators by which to judge the success of FP programs.

2.1. Knowledge Evaluation of Households on Family Planning in the Two Study Areas

a) Heard about the family planning 


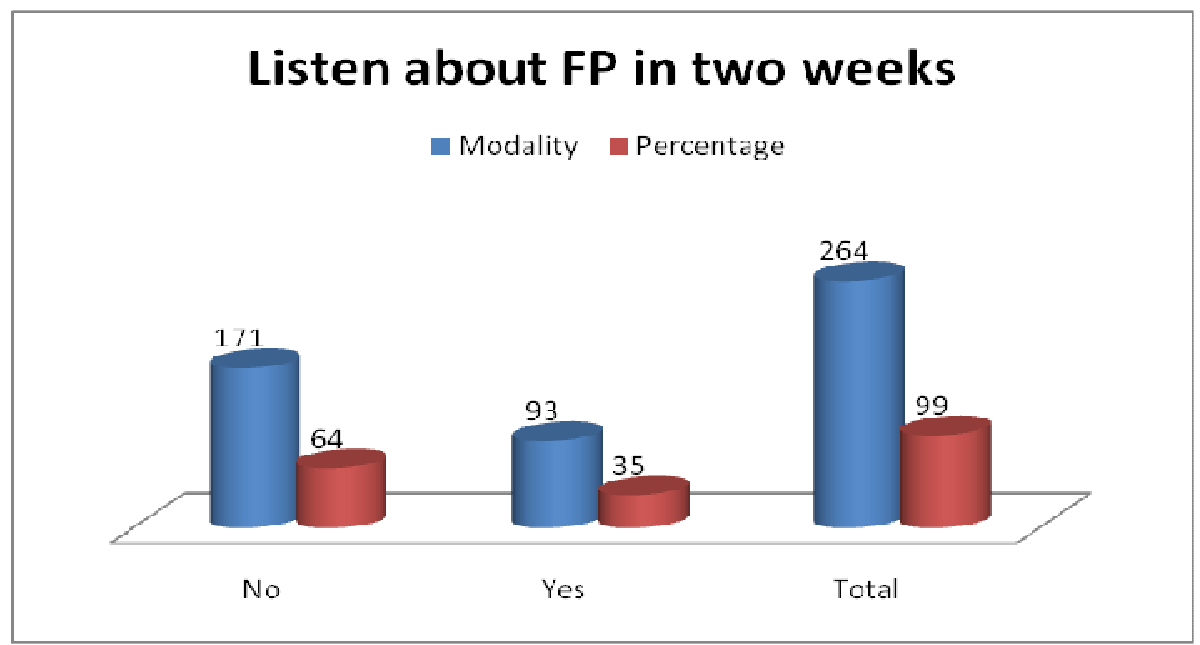

Graphic 3: The number of households who have just heard about the Family Planning within two weeks in the zone

Figure 3 shows that over half $(171 / 267)$ or $64 \%$ of respondents have already heard about FP and nearly half $(93 / 267) 35 \%$ have never heard, there is a big gap to fill in this country. Rozina Mustafa study and his collaborators done in Pakistan have had a contrary d) result from ours (Rozina, 2008); note that they have conducted their study in a rural area.

c) The advantages of the family planning

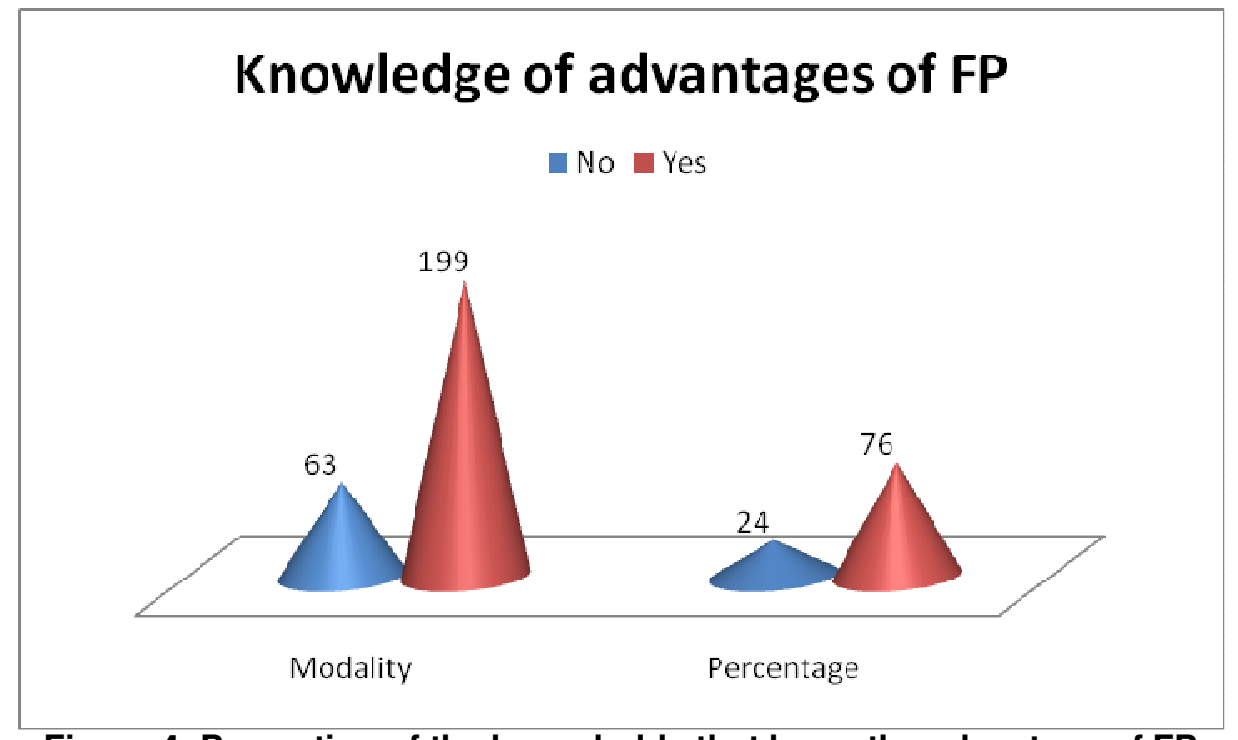

Figure 4: Proportion of the households that know the advantage of FP

Figure 4 shows that $76 \%$ of respondents are aware of the benefits of FP and the remaining $24 \%$ do not know. This large percentage of respondents that knows the advantages ought to influence the utilization of FP methods, but it is a paradoxical situation.

2.3.
2.2. The Knowledge of the advantages of the Family Planning according to sexes 


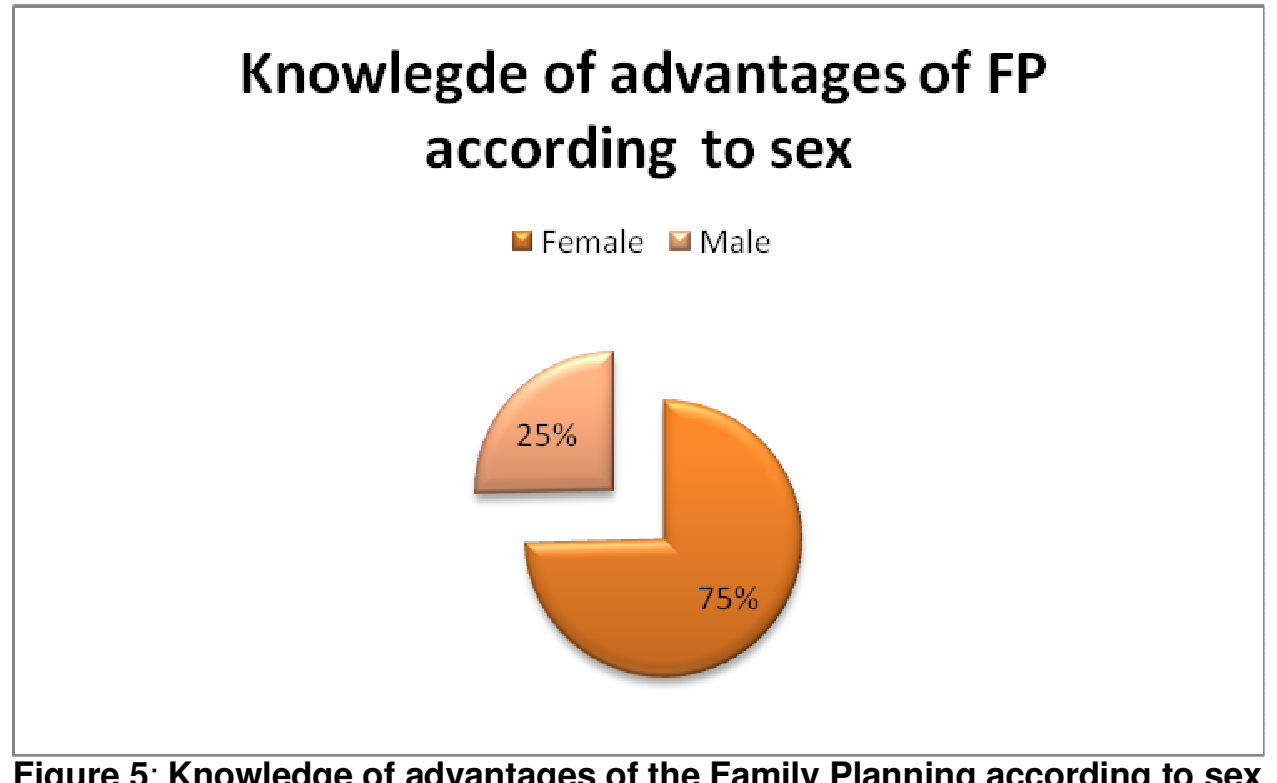

Figure 5 shows that in this area, those who know the benefits of FP are women with a proportion of $58 \%$ (153/262) while only (46/200) $24 \%$ are men. Since women use contraception much more than men and it is they who know the benefits and in principle, the use of

\section{5 .}

contraceptives should not be a problem, therefore, this makes it paradoxical.

2.4. The Known methods by the populations of Kadutu health zone

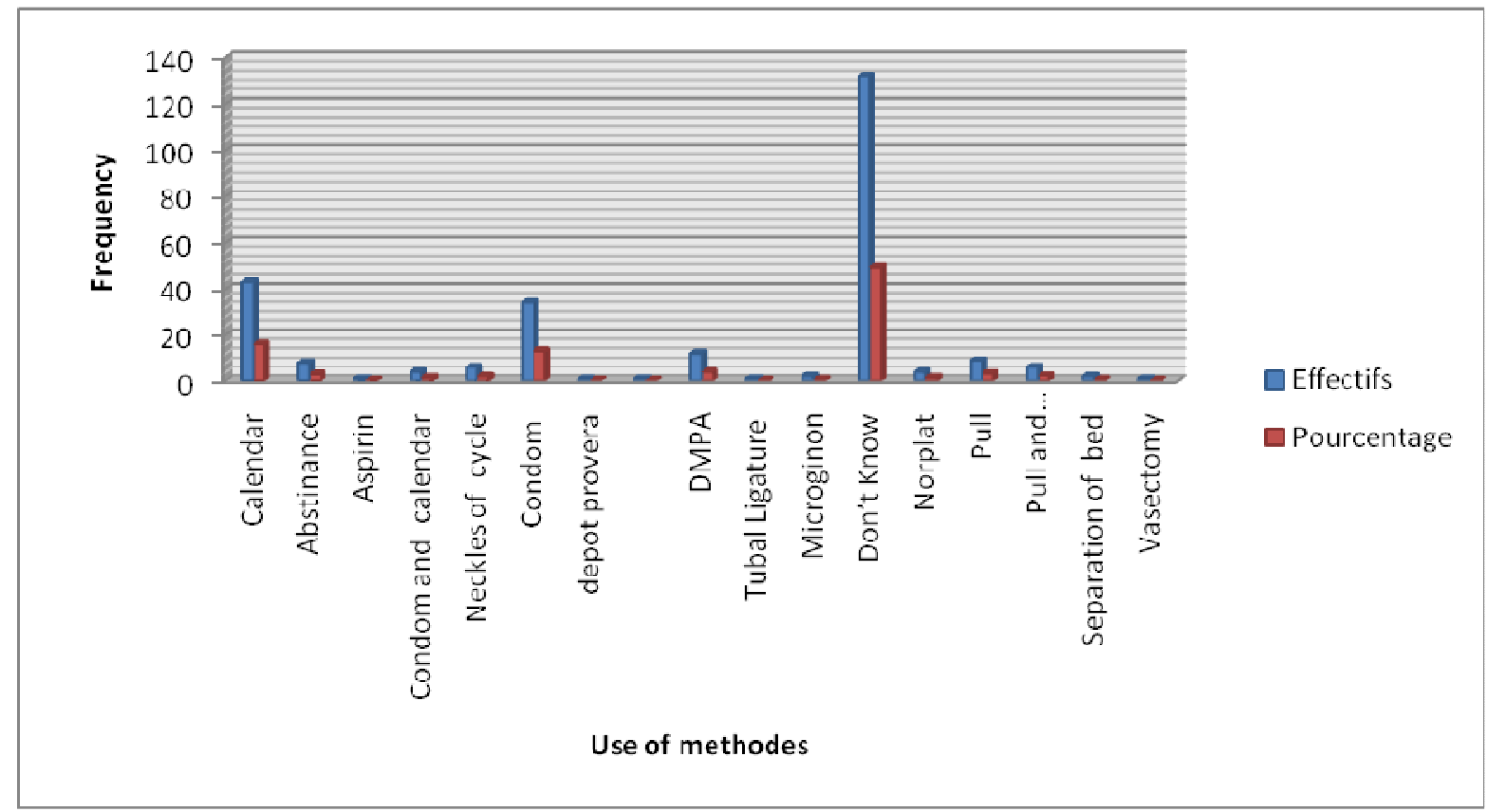

Figure 6: Known methods by the Kadutu populations

Figure 6 shows that almost half of the respondents, $49 \%$ (132/267) did not know about the contraceptives methods. The calendar methods which is also called natural method is known by $16 \% \quad(43 / 267), 13 \%$ (34/267) knew about condoms, 4\% (12/267) knew about DMPA (Acétate de Medroxy Progésterone Retard),
$3.3 \%(9 / 267)$ knew about the use of pills, 3\% (8/267) knew about abstinence, 2.3\% (6/267) knew about pills as wells as others methods like condom, calendar and injection and $2 \%$ (6/267) knew about the necklace of the cycle. Unfortunately some people think that aspirin can prevent conception or to keep towel cloths of 
menstruation without washing them can prevent conception. The first group has an odd knowledge and for the second group has the bases of their knowledge on customs, showing that South-Kivu customs continues to blind the population. A study done in Malian in 2012 publishes a similar result (Leon et al; 2012). Our worry is to realize that nearly half of the correspondents do not know contraceptive methods while in zone where there are many partners who promote this activity and several community sensitizations are done. In general view, many do not actually see the differences in the use of contraception, including modern contraception, but some contraceptive methods are more used than others (condom and calendar).

\section{IDENTIFICATION OF HINDRANCES CONTRACEPTIVE METHODS UTILIZATION}

\subsection{Bivariated Analysis of Hindrances to Contraceptive Methods Utilization}

Table 1 below show that:

\section{Age}

Among respondents in Kadutu who used contraceptive methods, $70.3 \%$ were aged less than or equal to 35 years and $29.7 \%$ were aged over 35 years. There is no statistically significant relationship between the age of respondents and the use of contraceptive methods in this area $(p>0.05)$.

\section{Denomination}

Among respondents in Kadutu who used contraceptive methods, $42 \%$ were churches other than the Roman Catholic and $38 \%$ were Church of the Catholic Church. There is a statistically significant relationship between religion and the use of contraceptive methods in Kadutu $(p<0.05)$. The assumption that religious denominations are an obstacle to the use of contraceptive methods has been verified and approved.

\section{Marital status}

Among respondents who have used contraception, $17.8 \%$ were married and $60 \%$ were singles. There is no statistically significant relationship between marital status and use of contraceptive methods in Kadutu ( $p>$ 0.05).

\section{Level of education}

Among respondents in Kadutu who used contraceptive methods, $25.2 \%$ had not studied or had not completed primary school and $74.8 \%$ had completed primary school and more. There is no statistically significant link between the level of education and the use of contraception in this Kadutu ( $p>0.05)$.

\section{Function}

Among respondents who have used contraception $56.6 \%$ were unemployed and $43.4 \%$ had employment. There is no statistically significant relationship between the function and use of contraceptive methods in Kadutu ( $p>0.05)$.

\section{Have heard about Family Planning}

Among respondents who have used contraception, 4.4\% have never heard about PF and $96 \%$ have heard about it. There is a very high statistically significant relationship expected between hearing about FP and use of contraceptive methods in Kadutu $(p=0.00)$. The CAP survey on FP Benin found that almost half of the respondents $(46.5 \%)$ had received a message on health in the last two weeks of investigations (Promote Integrated Family Health in Benin, CAP survey, 2002). They did not specify the type of message.

\section{Knowledge of the benefits of FP}

Among respondents who have used contraception $16.2 \%$ do not know the benefits of FP and $83.8 \%$ knows. There is no statistical significant link between marital status and use of contraceptive methods in Kadutu ( $p>0.05)$.

\section{Availability of inputs in structures}

Among respondents who have used contraception, $26.4 \%$ responded that the moments of FP were not available in clinics FP and $73.6 \%$ said they were there. There is a statistically significant link between the availability of inputs and the use of contraceptive methods Kadutu $(p=0.00)$. In Guinea we found similar results to ours (Mamadou, 2008).

\section{Geographical accessibility}

Among the respondents who used contraceptive methods, $99 \%$ have at least a half hour walk to get to the clinic FP and $1 \%$ have more than a half hour walk to get to the clinic of FP. There is no existing statistically significant link between the geographical accessibility and use of contraceptive methods in Kadutu ( $p>$ 0.05). Niyat Bangamboulou and his collaborators have found that it is the lack of information on these methods, the lack of FP centers and qualified personnel in FP as well as the cost that are causing this problem (Niyat et al., 2004).

\section{Waiting time for the board}


Among respondents who have used contraception, $58.8 \%$ have spent less than 25 minutes to be received at the clinic FP Board and $41.2 \%$ were made within 25 minutes. There is a statistically significant link between the waiting time and the use of contraceptive methods in Kadutu $(p<0.05)$.

\section{Number of children}

Among the respondents who used contraceptive methods, $54 \%$ has about or less than 4 children and $46 \%$ has more than 4 children. There is a statistically significant relationship between the number of children and the use of contraceptive methods in Kadutu ( $p>$ 0.05).

Table 1: The influencing factors of contraceptive methods

\begin{tabular}{|c|c|c|c|c|c|c|}
\hline \multirow[t]{3}{*}{ Variables } & \multicolumn{6}{|c|}{ KADUTU } \\
\hline & \multirow[t]{2}{*}{ Effective } & \multicolumn{2}{|c|}{$\begin{array}{l}\text { Utilization of contraceptives } \\
\text { methods }\end{array}$} & \multirow[t]{2}{*}{$X^{2}$} & \multirow[t]{2}{*}{$p$} & \multirow[t]{2}{*}{ Decision } \\
\hline & & No & Yes & & & \\
\hline $\begin{array}{l}\text { Age (in year) } \\
<=35 \\
>35 \\
\text { Total }\end{array}$ & $\begin{array}{l}78(70) \\
33(29.7) \\
111(100.0)\end{array}$ & $\begin{array}{l}185(73.4) \\
67(26.6) \\
\mathbf{2 5 2 ( 1 0 0 . 0 )}\end{array}$ & $\begin{array}{l}107(75.9) \\
34(24.1) \\
\mathbf{1 4 1 ( 1 0 0 . 0}\end{array}$ & 1.00 & 0.19 & NS \\
\hline $\begin{array}{l}\text { Religious confession } \\
\text { Other religion } \\
\text { Catholic } \\
\text { Total }\end{array}$ & $\begin{array}{l}124(48.4) \\
132(51.6) \\
\mathbf{2 5 6}(\mathbf{1 0 0 . 0})\end{array}$ & $\begin{array}{l}77(53.5) \\
67(46.5) \\
144(100.0)\end{array}$ & $\begin{array}{l}47(42) \\
65(38) \\
112(100.0\end{array}$ & 3.34 & 0.04 & * \\
\hline $\begin{array}{l}\text { Marital status } \\
\text { Non married } \\
\text { Married } \\
\text { Total }\end{array}$ & $\begin{array}{l}47(18.30) \\
210(81.3) \\
\mathbf{2 5 7 ( 1 0 0 . 0 )}\end{array}$ & $\begin{array}{l}31(21.4) \\
114(78.6) \\
145(100.0)\end{array}$ & $\begin{array}{l}16(14.3) \\
96(85.7) \\
\mathbf{1 1 2 ( 1 0 0 . 0}\end{array}$ & 2.128 & 0.09 & NS \\
\hline $\begin{array}{l}\text { Instruction level } \\
\text { No study and primary study } \\
\text { Primary study fullfilled and more } \\
\text { Total }\end{array}$ & $\begin{array}{l}67(26.2) \\
170(73.8) \\
\mathbf{2 4 2 ( 1 0 0 . 0 )}\end{array}$ & $\begin{array}{l}36(26.9) \\
98(73.1) \\
134(100.0)\end{array}$ & $\begin{array}{l}26(25.2) \\
77(74.8) \\
103(100.0\end{array}$ & 0.07 & 0.44 & NS \\
\hline $\begin{array}{l}\text { Function } \\
\text { jobless } \\
\text { with job } \\
\text { Total }\end{array}$ & $\begin{array}{l}136(56) \\
107(47) \\
\mathbf{2 4 3 ( 1 0 0 . 0 )}\end{array}$ & $\begin{array}{l}76(55.90 \\
61(44.1) \\
\mathbf{1 3 7 9 1 0 0 . 0 )}\end{array}$ & $\begin{array}{l}60(56.6) \\
46(43.4) \\
106(100.0)\end{array}$ & 0.03 & 0.48 & NS \\
\hline $\begin{array}{l}\text { Have heard talks about FP } \\
\text { Never } \\
\text { already } \\
\text { Total }\end{array}$ & $\begin{array}{l}34(13.3) \\
222(86.7) \\
\mathbf{2 5 6}(\mathbf{1 0 0 . 0 )}\end{array}$ & $\begin{array}{l}28(19.3) \\
117(80.7) \\
145(100.0)\end{array}$ & $\begin{array}{l}6(5.4) \\
105(94.6) \\
\mathbf{1 1 1 ( 1 0 0 . 0}\end{array}$ & 10.55 & 0.00 & *** \\
\hline $\begin{array}{l}\text { Knowledge of the advantages } \\
\text { of FP } \\
\text { They do not know } \\
\text { They know } \\
\text { Total }\end{array}$ & $\begin{array}{l}34(13.3) \\
22(86.7) \\
\mathbf{2 5 6 ( 1 0 0 . 0 )}\end{array}$ & $\begin{array}{l}28(19.3) \\
117(80.7) \\
\mathbf{1 4 5 ( 1 0 0 . 0 )}\end{array}$ & $\begin{array}{l}6(5.4) \\
105(94.6) \\
\mathbf{1 1 1 ( 1 0 0 . 0}\end{array}$ & 10.55 & 0.00 & *** \\
\hline Availability of input & & & & & & \\
\hline
\end{tabular}




\begin{tabular}{|c|c|c|c|c|c|c|}
\hline $\begin{array}{l}\text { No availability } \\
\text { availability } \\
\text { Total }\end{array}$ & $\begin{array}{l}\text { 73(36.7) } \\
126(63.3) \\
\mathbf{1 9 9 ( 1 0 0 . 0 )}\end{array}$ & $\begin{array}{l}45(48.4) \\
48(51.6) \\
96(100.0)\end{array}$ & $\begin{array}{l}28(26.4) \\
78(73.6) \\
106(53.3)\end{array}$ & 10.29 & 0.00 & $\star \star * *$ \\
\hline $\begin{array}{l}\text { Geographical accessibility } \\
\text { Walk less than } 1 \mathrm{~h} 30 \\
\text { Walk more than } 1 \mathrm{~h} 30 \\
\text { Total }\end{array}$ & $\begin{array}{l}228(98.7) \\
3(1.3) \\
\mathbf{2 3 1 ( 1 0 0 . 0 )}\end{array}$ & $\begin{array}{l}132(98.5) \\
2(1.5) \\
\mathbf{1 3 4 ( 1 0 0 . 0 )}\end{array}$ & $\begin{array}{l}96(99) \\
1(1) \\
97(100.0)\end{array}$ & 0.09 & 0.62 & NS \\
\hline $\begin{array}{l}\text { Waiting time for advice } \\
\text { Less than } 25 \text { minutes } \\
\text { More than } 25 \text { minutes } \\
\text { Total }\end{array}$ & $\begin{array}{l}110(46.20 \\
128(53.8) \\
238(100.0\end{array}$ & $\begin{array}{l}50(36.8) \\
86(63.2) \\
\mathbf{1 3 0 ( 5 7 . 1 )}\end{array}$ & $\begin{array}{l}60(58,8) \\
42(41.2) \\
102(100)\end{array}$ & 11.41 & 0.00 & $* * *$ \\
\hline $\begin{array}{l}\text { Number of children } \\
\text { Less than } 4 \text { children } \\
\text { More than } 4 \text { children } \\
\text { Total }\end{array}$ & $\begin{array}{l}115(55.6) \\
92(44.4) \\
\text { 207(100.0) }\end{array}$ & $\begin{array}{l}61(57) \\
46(43) \\
107(100.0)\end{array}$ & $\begin{array}{l}54(54) \\
46(46) \\
100(100.0\end{array}$ & 0.19 & 0.38 & NS \\
\hline
\end{tabular}

The parenthesis: The percentage

Signification level: ${ }^{*}: p$ value $<0.05 .{ }^{* *}: p<0.01 .{ }^{* * *}: p<0.001 . \quad$ NS: Non significative

\section{CONCLUSION AND RECOMMANDATION}

At the end of the study, 3 main sources of information on FP in the Health Zone are Kadutu radio, NPC and awareness campaigns with proportions $34.5 \%, 21.7 \%$ and $5.6 \%$ respectively. In this area, only $11.5 \%$ have no source of information. Households using contraception are $41 \%$ and unsatisfactory. In this area (150/267) or $54 \%$ households heard about PF, therefore, there is a large gap to fill. More than half of the respondents $64 \%$ were not still informed about FP the last two weeks and only $34.8 \%$ were informed. The lack of availability of inputs and waiting time (over 25 minutes) to the Board in clinical FP are key factors for non-use of contraceptive methods.

Moreover, in this country, respondents' religious denominations other than the Catholic Church and those who have never heard about PF tend not to use contraceptive methods. It is shown that in Kadutu the FP is more interested in women than men and the population of this area has not been able to cite the methods accurately.

Given these results, we recommend the following:

1. NRHP and NGOs working in the field of Reproductive Health make available inputs of FP and train providers in respect to the waiting time recommended by the $\mathrm{WHO}$;

2. Providers of Reproductive Health to accelerate awareness in the community, churches and also orientate the men.

\section{REFERENCES}

Atelier de formation sur les audits/revues des décès maternels et néonataux, OMS-Mauritanie, Août 2007.

Borgou et l'Alibori, Enquête sur les Connaissances, Attitudes et Pratiques en Matière de Santé Familiale au Benin 2002.

Déclaration D'ALMA-ATA, Organisation Mondiale de la Santé - 12 septembre 1978.

Demographic and Health Survey, 2010. Preliminary Report Addai, Determinants of use of maternal-child health services in rural Ghana. Journal of Biosocial Science 32(1):1-15.

Dieudonné Niyat Bangamboul. La Planification Familiale en République Centrafricaine : Bilan et recommandations, 2004.

Enquête CAP sur la Planification Familiale et la survie de l'enfant de 2004 en Guinée.

Enquête Démographique et de Santé (EDSB-III) Bénin 2009.

Joseph V. et Garenne M., 2001, Datation de la baisse de la fécondité en Afrique subsaharienne. Paris, Les Dossiers du CEPED, $n^{\circ} 66,64 \mathrm{p}$.

La mortalité maternelle en 2005, Estimation de l'OMS, I'UNICEF, I'UNFPA et la Banque Mondiale.

Leon Bijlmakers et all, La pràtique contraceptive et la contribution des activités de PF au Mali, 2012.

Mamadou Chérif BAH, Planification Familiale en Guinée, 2008.

Ministère du Plan avec la collaboration du Ministère de la Santé Kinshasa, République Démocratique du Congo, Enquête démographique et de santé en 
RDC 2007 [Demographic and Health Survey 2007]. Calverton, Maryland, U.S.A.: Ministère du Plan et Macro International.

National Institute of Statistics of Rwanda, Ministry of Finance and Economic Planning, Ministry of Health Rwanda, measure DHS, ICF Macro, Demographic and Health Survey 2010, Preliminary Report Addai, Determinants of use of maternal-child health services in rural Ghana. Journal of Biosocial Science 32(1):1-15.

OMS 1985, Déclaration du Millénaire des Nations Unies. Cinquante-cinquième session de l'Assemblée générale des Nations Unies, New York: Nations Unies; 18 septembre 2000 (document de l'Assemblée générale $A / R E S / 55 / 2$.).

OMS, Conférence Internationale sur la population et développement, Caire, 1994.

PNSR, Kinshasa 2008, Module de formation des prestataires en PF.
Rapport annuel de Programme Nationale de la Santé Reproductive au Sud-Kivu, 2012.

République du Bénin, Ministère de la Santé Publique, Direction Départementale de la Santé Publique du Borgou et de l'Alibori, Promotion Intégrée de Santé Familiale dans le Borgou et l'Alibori (PROSAF), Bebin, 2012.

Ross, J. and E. Smith): Trends in National Family Planning Program, 1999, 2004 and 2009. International Perspectives on Sexual and Reproductive Health 37(3): 125-133, 2011.

Rozina Mustafa, Uzma Afreen and Haleema A. Hashmi, Contraceptive Knowledge, Attitude and Practice Among Rural Women, 2008, Pakistan.

Thierry Ancelle et al, statistique épidémiologie, édition Maloine-23, rue de l'école-de-Médecine, 75006 Paris, p78. 